\title{
High glucose decreases intracellular glutathione concentrations and upregulates inducible nitric oxide synthase gene expression in intestinal epithelial cells
}

\author{
Lesley A Powell ${ }^{1}$, Katherine $\mathbf{M}$ Warpeha ${ }^{2}$, Weiming $\mathbf{X u}^{3}$, Brian Walker ${ }^{2}$ and \\ Elisabeth R Trimble ${ }^{1,4}$ \\ 1Department of Clinical Biochemistry and Metabolic Medicine, Institute of Clinical Science, Queen's University Belfast, Grosvenor Road, Belfast BT12 \\ $6 \mathrm{BJ}, \mathrm{UK}$ \\ 2School of Pharmacy, Queen's University Belfast, Belfast, UK \\ ${ }^{3}$ Wolfson Institute for Biomedical Research, University College London, London, UK \\ ${ }^{4}$ Department of Clinical Biochemistry, The Royal Group of Hospitals, Belfast, UK
}

(Requests for offprints should be addressed to L Powell; Email: I.powell@ qub.ac.uk)

\begin{abstract}
Diabetes is associated with oxidative stress and increased concentrations of inflammatory cytokines. The aim of the study was to assess the effects of inflammatory cytokines and oxidative stress associated with increased glucose concentrations on inducible nitric oxide synthase (iNOS) promoter activity in intestinal epithelial cells. High-glucose $(25 \mathrm{mmol} / \mathrm{l})$ conditions reduced glutathione $(\mathrm{GSH})$ concentrations in the human intestinal epithelial cell line, DLD-1. Addition of the antioxidant, $\alpha$-lipoic acid, resulted in the restoration of GSH concentrations to normal. Upregulation of basal iNOS promoter activity was observed when cells were incubated in high glucose alone. This effect was significantly reduced by the addition of the antioxidant, $\alpha$-lipoic acid, and completely blocked with inhibition of nuclear factor kappa $B\left(N F_{\kappa B}\right)$ activity. Stimulation of cytokines (interleukin-1 beta, tumour necrosis factor-alpha, interferon-gamma) induced iNOS promoter activity in all conditions and this was accompanied by an increase in nitric oxide (NO) production. Inhibition of NFKB activity decreased, but did not completely inhibit, cytokine-induced iNOS promoter activity and subsequent production of NO. In conclusion, iNOS promoter activity induced by high concentrations of glucose is mediated in part through intracellular GSH and NFKB.
\end{abstract}

Journal of Molecular Endocrinology (2004) 33, 797-803

\section{Introduction}

Relatively little is known about the effect of diabetes on intestinal epithelium in the absence of autonomic neuropathy. It is well recognized that diabetes induces oxidative stress and that the resulting oxidative damage has a key role in the development of diabetic complications (Son et al. 2004). Within the small intestine, diabetes is associated with numerous changes, including hyperplasia and hypertrophy of epithelial cells (Zoubi et al. 1995), increased absorption of sugars and amino acids (Fedorak 1990) and increased endogenous cholesterol synthesis (Feingold et al. 1982). Inflammatory cytokines are also increased in diabetes (Esposito et al. 2002). It is believed that increases in human histocompatibility antigens (HLA) class II, HLA-DR and HLA-DP, found in structurally normal intestine in diabetic individuals, may result from secretion of inflammatory cytokines such as interferon gamma (IFN- $\gamma$ ) (Savilahti $e t$ al. 1999). Cytokines also modulate gut permeability (McKay \& Baird 1999), but there does not appear to be a consensus about the presence of altered gut permeability in diabetes. Differences in opinion may reflect differences in methodologies used by various investigators.

One of the important regulatory signalling molecules produced by the endothelium is nitric oxide (NO), which is synthesized from L-arginine by the action of three different isozymes of nitric oxide synthase (NOS) (Moncada \& Higgs 1993). 
NO can have either protective or deleterious effects in the gastrointestinal tract; NO generated by the action of constitutive NOS (cNOS) acts physiologically and the overproduction of $\mathrm{NO}$ by inducible NOS (iNOS) occurs during pathophysiological conditions. Intestinal permeability is also increased when iNOS concentrations are very high (Kilbourn \& Griffith 1992). Smaller increases in iNOS are associated with epithelial repair after injury (Gookin et al. 2002). High concentrations of NO produced from iNOS exhibit toxic effects through nitrosative and oxidative stress; however, regulation of the induction of iNOS in diabetes remains unclear. The aim of this study was to assess the effect of inflammatory cytokines and oxidative stress associated with increased glucose concentrations on iNOS promoter activity in intestinal epithelial cells.

\section{Materials and Methods}

\section{Materials and reagents}

All chemicals were obtained from Sigma and tissue culture reagents were purchased from Invitrogen Ltd, unless otherwise stated. The cytokines were purchased from R\&D Systems (Abingdon, UK). The synthetic peptidyl alpha-keto aldehyde proteasome inhibitor was synthesized on an ABI/Pioneer automated peptide synthesizer (Lynas et al. 1998).

\section{Tissue culture}

The human colon-carcinoma-derived epithelial cell line, DLD-1 (Dexter et al. 1979) was maintained in 10\% Dulbecco's modified Eagle medium supplemented with antibiotics $(100 \mu \mathrm{g} / \mathrm{ml}$ streptomycin sulphate, $\quad 60 \mu \mathrm{g} / \mathrm{ml}$ benzylpenicillin) and L-glutamine $(2 \mathrm{mmol} / \mathrm{l})$ in a humidified atmosphere of $5 \% \mathrm{CO}_{2}$. To determine if changes in iNOS transcription are caused by high glucose, glycation or osmotic effects, experiments were performed over a 48 -h period using normal glucose $(5 \mathrm{mmol} / \mathrm{l}$; $\mathrm{N})$, high glucose $(25 \mathrm{mmol} / \mathrm{l} ; \mathrm{H})$ and the nonmetabolizable L-glucose (5 mmol/l D-glucose + $20 \mathrm{mmol} / \mathrm{l} \mathrm{L}$-glucose; L). The antioxidant, $\alpha$-lipoic acid $(50 \mu \mathrm{mol} / \mathrm{l} ; \mathrm{LA})$, which replenishes reduced glutathione $(\mathrm{GSH})$, was added to high-glucose experiments to assess the effect of GSH on cytokine-induced transcriptionof iNOS. The NFкB inhibitor was reconstituted in dimethyl sulphoxide and used at a concentration of $50 \mu \mathrm{mol} / \mathrm{l}$ (NI) for $4 \mathrm{~h}$.

\section{Determination of intracellular glutathione}

GSH determination was performed using an enzymatic recycling assay as previously described, which has been automated on the Cobas Fara centrifugal analyser (Sharpe et al. 1998). GSH concentrations were corrected for protein concentration.

\section{iNOS construct}

The $-7 \cdot 2 \mathrm{~kb}$ human iNOS promoter fragment (David Geller, University of Pittsburgh, USA) contains the unique human enhancer region, which includes four NFKB binding sites critical for transcriptional regulation of iNOS (Taylor et al. 1998). This large clone, $-7 \cdot 2 \mathrm{~kb}$ luc (sequence in Genbank AF093682), is in the parent luciferase vector, pXP2.

\section{Transient transfection}

Cells were seeded into 12-well plates and at 70\% confluence were treated with Superfect (Qiagen, West Sussex, UK) containing 1-2 $\mu \mathrm{g}$ of the fulllength construct described above, and $0 \cdot 2-0 \cdot 4 \mu \mathrm{g}$ $p R L-T K$, a renilla luciferase gene under control of a TK promoter as an internal control. After transfection for $48 \mathrm{~h}$, cells were treated for $4 \mathrm{~h}$ with the proinflammatory cytokine cocktail containing interleukin 1-beta (IL-1 $\beta ; 2 \mathrm{ng} / \mathrm{ml}$ ), tumour necrosis factor alpha (TNF- $\alpha ; 10 \mathrm{ng} / \mathrm{ml}$ ) and interferon gamma (IFN- $\gamma ; 1000 \mathrm{IU} / \mathrm{ml})$ to induce iNOS gene expression. The dual-luciferase reporter assay system (Promega) was used to quantitate the luminescent signal from firefly and renilla luciferase. Luminescence was measured on a TopCount NXT microplate scintillation and luminescence counter (Packard). Transfections were performed in triplicate and normalized against the control activity from the renilla luciferase.

\section{Nitrite/nitrate production}

Nitrites and nitrates were measured spectrofluorimetrically using the 2,3-diaminonaphthotriazole (DAN) reagent. Briefly, cell culture supernatants were incubated with NADPH $(67 \mu \mathrm{mol} / \mathrm{l}$, 
Boehringer-Mannheim) and nitrate reductase $(0 \cdot 14$ $\mathrm{IU} / \mathrm{ml})$ for $10 \mathrm{~min}$. DAN reagent $(0.05 \mathrm{mg} / \mathrm{ml})$ was added after $10 \mathrm{~min}$ and incubated for a further $10 \mathrm{~min}$. The reaction was stopped by the addition of sodium hydroxide $(2 \cdot 8 \mathrm{~mol} / \mathrm{l})$. Standard curves were produced under the same experimental conditions using nitrate solutions $(0 \cdot 5-50 \mu \mathrm{mol} / \mathrm{l})$. The formation of DAN was measured (excitation $360 \mathrm{~nm}$, emission $465 \mathrm{~nm}$ ) using a Genios fluorescence spectrophotometer (Tecan, Austria) and corrected for protein concentration.

\section{Statistics}

Data were analysed using analysis of variance and multiple comparisons between data sets were made using modified $t$-tests only if the overall value of $P$ was less than 0.05. All results are expressed as mean \pm S.E.M. of at least three independent experiments performed in triplicate.

\section{Results}

\section{Glucose-induced changes in GSH}

GSH concentrations in transfected DLD-1 cells were decreased in high-glucose conditions (1.56 \pm $0.07 \mathrm{nmol} / \mathrm{mg}$ protein) compared with normalglucose conditions $(2 \cdot 18 \pm 0.07 \mathrm{nmol} / \mathrm{mg}$ protein; $P<0.05, n=3)$ and could be restored by the addition of the antioxidant, $\alpha$-lipoic acid $(2 \cdot 10$ $\pm 0 \cdot 04 \mathrm{nmol} / \mathrm{mg}$ protein; $P<0 \cdot 05, n=3)$. Inhibition of NFKB activity increased GSH concentrations to significantly above normal in glucose-treated cells $(5 \cdot 84 \pm 0 \cdot 48 \mathrm{nmol} / \mathrm{mg}$ protein; $P<0 \cdot 005, n=3)$.

\section{iNOS promoter activity}

High glucose $(25 \mathrm{mmol} / \mathrm{l})$ caused an increase in iNOS promoter activity to a level approximately $250 \%$ of that found with normal ( $5 \mathrm{mmol} / \mathrm{l}$ ) glucose (Fig. 1). This effect was significantly reduced by the addition of the antioxidant, $\alpha$-lipoic acid, and completely blocked with NFKB inhibition (Fig. 1).

In all experimental conditions, the iNOS promoter activity induced by the cocktail of cytokines was above basal (Fig. 1). The restoration of GSH concentrations with $\alpha$-lipoic acid (in high glucose) had no effect on the response of the iNOS promoter to cytokines; in contrast, the presence of

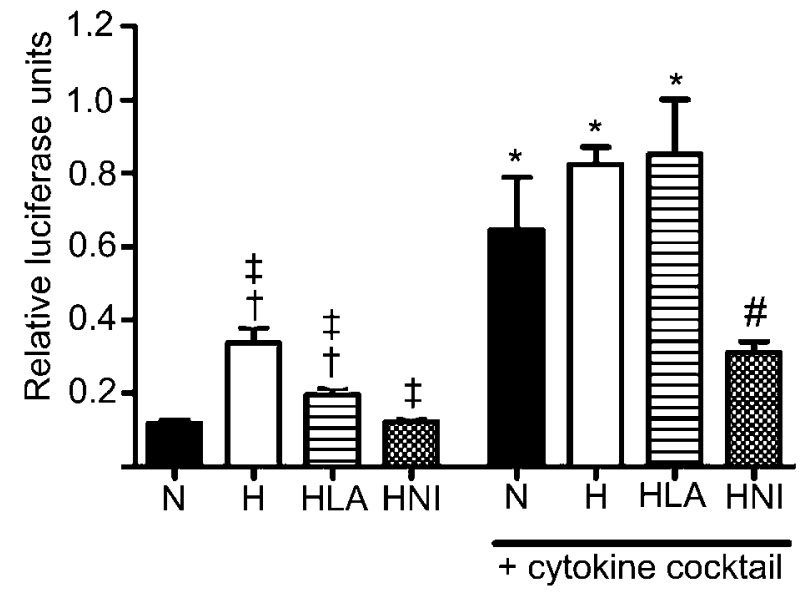

Figure 1 iNOS promoter activity. Cells were transfected with $-7.2 \mathrm{~kb}$ luc construct and incubated for $48 \mathrm{~h}$ before the addition of a cocktail of cytokines (IL-1 $\beta 2 \mathrm{ng} / \mathrm{ml}$, TNF- $\alpha 10 \mathrm{ng} / \mathrm{ml}$ and IFN- $\gamma 1000 \mathrm{IU} / \mathrm{ml}$ ) for $4 \mathrm{~h}$ in the following conditions: $\mathrm{N}=$ normal glucose $(5 \mathrm{mmol} / \mathrm{l}$ D-glucose); $\mathrm{H}=$ high glucose (25 mmol/l D-glucose); $\mathrm{HLA}=$ high glucose with $\alpha$-lipoic acid $(50 \mu \mathrm{mol} / \mathrm{l})$; $\mathrm{HNI}=$ high glucose with the NFKB inhibitor $(50 \mu \mathrm{mol} / \mathrm{l})$. Values are expressed as mean relative luciferase units \pm S.E.M. ${ }^{*} P<0.05$ compared with non-induced (no cytokine cocktail); $\uparrow P<0.05$ compared with $\mathrm{N}, \ddagger P<0.05$ compared with $\mathrm{N}+$ cytokine cocktail, $\# P<0.05$ compared with $\mathrm{H}+$ cytokine cocktail). Experiments were performed in triplicate and the results are representative of at least three independent experiments.

the NFкB inhibitor significantly decreased the iNOS promoter response to cytokines in both high glucose (Fig. 1) and normal glucose $(0 \cdot 64 \pm 0 \cdot 14$ relative luciferase units (RLU) for normal glucose, compared with $0 \cdot 28 \pm 0 \cdot 07$ RLU for normal glucose with NFкB inhibitor; $P<0 \cdot 05, n=3$ ).

Under physiological conditions, intestinal epithelial cells are exposed to a wider range of osmotic pressures than most other cells of the body. It seemed important to determine whether the effects of glucose, described above, were attributable to increased osmotic pressure. The use of the non-metabolizible analogue, L-glucose, allowed us to explore this possibility in addition to determining whether glucose metabolism was required for the effects on the iNOS promoter. iNOS promoter activity was similar in the presence of $5 \mathrm{mmol} / \mathrm{l}$ D-glucose and $5 \mathrm{mmol} / \mathrm{l} \mathrm{D}$-glucose plus $20 \mathrm{mmol} / \mathrm{l}$ L-glucose. Furthermore, the effect of cytokines on promoter activity was similar under these two experimental conditions (Fig. 2). Thus osmotic pressure could not explain the effect of $\mathrm{D}$-glucose on 


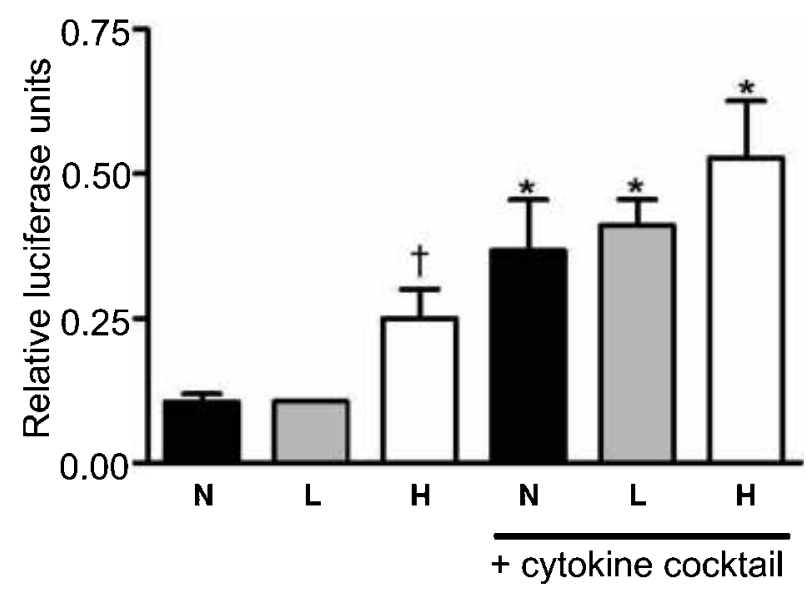

Figure 2 iNOS promoter activity. Cells were transfected with $-7.2 \mathrm{~kb}$ luc construct and incubated for $48 \mathrm{~h}$ before the addition of a cytokine cocktail (IL-1 $\beta 2 \mathrm{ng} / \mathrm{ml}$, TNF- $\alpha$ $10 \mathrm{ng} / \mathrm{ml}$ and IFN- $\gamma 1000 \mathrm{IU} / \mathrm{ml}$ ) for $4 \mathrm{~h}$ in the following conditions: $\mathrm{N}=$ normal glucose $(5 \mathrm{mmol} / \mathrm{l} \mathrm{D}$-glucose); $\mathrm{L}=$ combination of normal glucose $(5 \mathrm{mmol} / \mathrm{l} \mathrm{D}$-glucose $)+$ L-glucose $(20 \mathrm{mmol} / \mathrm{l}$ L-glucose); $\mathrm{H}=$ high glucose (25 mmol/l D-glucose). Values are expressed as mean relative luciferase units \pm S.E.M. ${ }^{*} P<0.05$ compared with non-induced (no cytokine cocktail); $† P<0.05$ compared with $\mathrm{N}$. Experiments were performed in triplicate and the results are representative of at least three independent experiments.

iNOS promoter activity. The results clearly demonstrate that the metabolism of glucose is required in order to increase promoter activity.

\section{Nitrite/nitrate production}

The upregulation of iNOS promoter activity in high-glucose conditions was not accompanied by significant changes in NO production. In contrast, the cytokine cocktail (IL- $1 \beta$, TNF- $\alpha$, IFN- $\gamma$ ) increased $\mathrm{NO}$ production in all experimental conditions tested (Table 1). As observed with iNOS promoter activity, restoration of GSH concentrations with the addition of $\alpha$-lipoic acid had no significant effect on cytokine-induced production of NO. Inhibition of NF $\mathrm{NB}$ activity reduced, but not significantly, the production of NO in cells treated with high concentrations of glucose (Table 1).

\section{Discussion}

This study has shown that exposure of human DLD-1 cells to high concentrations of glucose
Table 1 Nitrite/nitrate production. Cells were transfected with $-7.2 \mathrm{~kb}$ luc construct and incubated with $5 \mathrm{mmol} / \mathrm{l}$ glucose (normal; N) or $25 \mathrm{mmol} / \mathrm{l}$ glucose (high; H), $50 \mu \mathrm{mol} / / \mathrm{l} \alpha$-lipoic acid (LA) or an NFKB inhibitor $(50 \mu \mathrm{mol} / \mathrm{l} ; \mathrm{NI})$ for $48 \mathrm{~h}$ before the addition of a cytokine cocktail (IL- $1 \beta 2 \mathrm{ng} / \mathrm{ml}$, TNF- $\alpha 10 \mathrm{ng} / \mathrm{ml}$ and IFN- $\gamma$ $1000 \mathrm{IU} / \mathrm{ml}$ ) for $16 \mathrm{~h}$. Production of NO was quantified, corrected for protein concentration, and the results expressed as mean \pm S.E.M. ( $\mu \mathrm{mol} / \mathrm{mg}$ protein). Experiments were performed in triplicate and the results are of at least three independent experiments

\begin{tabular}{llll} 
& $\begin{array}{l}\text { Non-induced } \\
(\mu \mathrm{mol} / \mathrm{mg} \text { protein })\end{array}$ & & $\begin{array}{l}\text { Cytokine-stimulated } \\
(\mu \mathrm{mol} / \mathrm{mg} \text { protein })\end{array}$ \\
\cline { 2 - 2 } & $0.87 \pm 0.11$ & & $7.50 \pm 0.37^{*}$ \\
$\mathrm{H}$ & $0.72 \pm 0.10$ & & $6.89 \pm 0.24^{*}$ \\
$\mathrm{HLA}$ & $1.44 \pm 0.18$ & $8.24 \pm 1.21^{*}$ \\
$\mathrm{HNI}$ & $1.13 \pm 0.21$ & $4.40 \pm 1.57$
\end{tabular}

${ }^{*} P<0.05$ compared with non-induced (no cytokine).

(25 mmol/l) for $48 \mathrm{~h}$ decreases intracellular GSH concentrations and supports the evidence that hyperglycaemia induces oxidative stress in the gastrointestinal tract (Bhor et al. 2004). GSH concentrations, reduced by glucose, were restored to normal by addition of the antioxidant, $\alpha$-lipoic acid. A similar result has been observed in human vascular smooth muscle cells (Powell et al. 2001), mesangial cells (Catherwood et al. 2002) and human peripheral mononuclear cells of patients with non-insulin-dependent diabetes (Arnalich et al. 2001). $\alpha$-Lipoic acid not only functions as an antioxidant, but is reduced to dihydrolipoate intracellularly, thereby increasing the availability of the rate-limiting substrate in GSH synthesis, cysteine. It is also possible that the restoration of GSH concentrations may result from the direct effects of $\alpha$-lipoic acid on gene expression of the gamma-glutamylcysteine synthetase $(\gamma$-GCS) subunits (Suh et al. 2004). We also observed that, when $\mathrm{NF \kappa B}$ is inhibited, GSH concentrations are increased substantially above normal. This suggests that, under basal conditions, NFאB has a negative regulatory effect on GSH. Transcription factor binding sites, including $\mathrm{NF \kappa B}$, have been identified in the promoter region of the light subunit of $\gamma$-GCS, but the specific role of NFKB in regulation requires further investigation.

To determine the effects of high concentrations of glucose on iNOS transcription, experiments were performed using normal glucose $(5 \mathrm{mmol} / \mathrm{l})$, 
high glucose $(25 \mathrm{mmol} / \mathrm{l})$ and the nonmetabolizible L-glucose (5 mmol/l D-glucose + $20 \mathrm{mmol} / \mathrm{l} \mathrm{L}$-glucose). Whereas Linn et al. (1997) were unable to show cytokine induction of an iNOS promoter in DLD-1 cells using a promoter construct less than $-8.7 \mathrm{~kb}$, we have shown increased promoter activity using a construct of $-7 \cdot 2 \mathrm{~kb}$ and a cytokine cocktail consisting of IL- $1 \beta$, TNF- $\alpha$ and IFN- $\gamma$, in the presence of both normal and high concentrations of glucose. This increase was not changed by glycation or osmotic effects and was undiminished in the presence of the antioxidant, $\alpha$-lipoic acid, which restores GSH to normal concentrations in cells treated with high concentrations of glucose.

In addition, when DLD- 1 cells were incubated in high-glucose conditions, there was a significant increase in iNOS promoter activity in cells that were not stimulated by cytokines. This effect may be mediated by GSH via NFkB, as restoration of GSH concentrations with $\alpha$-lipoic acid and NFкB inhibition reduced iNOS promoter activity to near normal. High glucose also increased cytokineinduced increases in iNOS promoter activity, with the exception of cells treated with the NFкB inhibitor. High concentrations of glucose have been shown to increase cytokine-induced increases in iNOS protein (Xu et al. 1999) and mRNA (Noh et al. 2002) in rat tissues. However, in contrast to our observation that high glucose increases iNOS promoter activity in non-cytokine-stimulated cells, it has been reported that, in bovine aortic endothelial cells, high concentrations of glucose $(25 \mathrm{mmol} / \mathrm{l})$ inhibit lipopolysaccharide-induced production of $\mathrm{NO}$ by decreasing the expression of iNOS and cNOS (Guo et al. 2000). GSH has been shown to regulate IL-1 $\beta$-induced production of NO in islets, purified $\beta$ cells and insulinoma cells by modulation of iNOS gene expression (Nikulina et al. 2000). Miralles et al. (2000) observed that molecular oxygen was able to regulate expression of iNOS in rat liver at the transcriptional level, through the production of reactive oxygen species and reduction in $\mathrm{GSH}$.

The effects of glucose treatment may be dependent on the duration of exposure. Stockklauser-Färber et al. (2000) observed that the activity of total NOS and mRNA were dependent on the duration of diabetes in rat hearts, in which there was an increase in activity after 4-6 weeks, but a reduction after 20 weeks. It is now apparent that the mechanisms by which glucose may influence iNOS regulation may be cell-typedependent. In rat pancreatic $\beta$ cells, high concentrations of glucose are believed to enhance IL-1 $\beta$-induced production of $\mathrm{NO}$ via the p38 signalling pathway (Nikulina et al. 2000). Chronic treatment with supraphysiological concentrations of insulin $(100 \mathrm{nmol} / \mathrm{l})$ and insulin resistance induced by high glucose treatment ( $25 \mathrm{mmol} / \mathrm{l}$ for $12-24 \mathrm{~h}$ ) are accompanied by marked reductions in iNOS as a result of p38 mitogen-activated protein kinase (MAPK) activation in rat aortic vascular smooth muscle cells (Begum \& Ragolia 2000). Addition of a protein kinase $\mathrm{C}$ inhibitor, calphostin $\mathrm{C}$, and an aldose reductase inhibitor suppressed the enhancement of cytokine-induced production of $\mathrm{NO}$ by high concentrations of glucose $(30 \mathrm{mmol} / \mathrm{l})$ in rat mesangial cells (Loven et al. 1986).

$\mathrm{NF \kappa B}$, an oxidative-stress-responsive transcription factor, is activated in cells cultured in high-glucose conditions (Hattori et al. 2000, Du et al. 1999) and mediates cytokine-induced expression of iNOS in various cell types (Kwon et al. 1995, 1998). However, in DLD-1 cells, the inhibition of NFKB activity appears to reduce cytokine-induced iNOS promoter activity, and to abolish completely the observed increase in iNOS promoter activity induced by glucose. The inhibition of NFKB activity also reduces, but does not completely abolish, subsequent production of $\mathrm{NO}$ in cells treated with high concentrations of glucose. There are conflicting reports on the involvement of glucose, GSH and NFKB in the regulation of iNOS (Guo et al. 2000, Miralles et al. 2000, Nikulina et al. 2000, Stockklauser-Färber et al. 2000) and this evidence, together with our findings, suggests that the regulation of iNOS by GSH and NFKB is species- or cell-specific (or both). The exact mechanism of iNOS regulation in DLD-1 cells remains to be elucidated, but from the findings of the present study it is apparent that the mechanism by which high concentrations of glucose regulate iNOS differs from cytokine-induced activation. Cytokine-induced activation of iNOS in DLD-1 cells is independent of protein kinases $\mathrm{A}, \mathrm{C}$ and $\mathrm{G}$, phosphatidylinositol 3-kinase (PI3K), extracellularregulated kinase and p38 MAPK, but requires protein tyrosine activity, especially that of IFN- $\gamma$ activated janus-activated kinase 2 (JAK 2) (Cavicchi \& Whittle 1999). It is possible that protein kinase signalling pathways such as p38 MAPK and PI3K, 
which are activated by high glucose concentrations in other cell types (Wilmer et al. 2001, Srivastava 2002), are involved in this regulation. The activation of iNOS that is induced by high concentrations of glucose may also involve other non-redox-sensitive transcription factors such as signal transducer and activator of transcription-1 (STAT-1), which can be phosphorylated by protein kinases such as JAK1/2.

In summary, this study has shown that, in DLD-1 cells, stimulation by cytokines (IL-1 $\beta$, TNF- $\alpha$, IFN- $\gamma$ ) induces iNOS promoter activity, resulting in an increase in $\mathrm{NO}$ production, and that this effect is mediated in part by the redox-sensitive transcription factor, NFKB. High concentrations of glucose alone also induce basal iNOS promoter activity through changes in intracellular GSH and

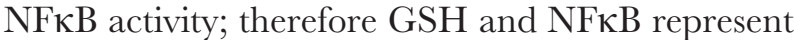
potential targets for therapeutic intervention to alleviate the complications of long-term diabetes. Maintenance of GSH concentrations using the antioxidant, $\alpha$-lipoic acid, may prove beneficial in the inhibition of hyperglycaemia-induced oxidative responses during diabetes.

\section{Acknowledgements}

The authors wish to thank Dr David Gellar (University of Pittsburgh, USA) for the kind donation of the $-7 \cdot 2 \mathrm{~kb}$ human iNOS promoter fragment and Dr Lizhi Lui (The Wolfson Institute, UCL, London) for her technical expertise and help with transfection. This study was supported by a small grant from Diabetes UK (reference no. BDA:RD00/0002188).

\section{References}

Arnalich F, Hernanz A, Lopez-Maderuelo D, De la Fuente M, Arnalich FM, Andres-Mateos E, Fernandez-Capitan C \& Montiel C 2001 Intracellular glutathione deficiency is associated with enhanced nuclear factor-kappaB activation in older non-insulin dependent diabetic patients. Free Radical Research 35 873-874.

Begum N \& Ragolia L 2000 High glucose and insulin inhibit VSMC MKP-1 expression by blocking iNOS via p38 MAPK activation. American fournal of Physiology: Cell Physiology 278 C81-C91.

Bhor VM, Raghuram N \& Sivakami S 2004 Oxidative damage and altered antioxidant enzyme activities in the small intestine of streptozotocin-induced diabetic rats. International fournal of Biochemical Cell Biology 36 89-97.

Catherwood MA, Powell LA, Anderson P, McMaster D, Sharpe PC \& Trimble ER 2002 Glucose-induced oxidative stress in mesangial cells. Kidney International 61 599-608.
Cavicchi M \& Whittle BJ 1999 Regulation of iNOS and the inhibitory actions of dexamethasone in the human intestinal epithelial cell line, Caco-2: influence of cell differentiation. British Fournal of Pharmacology 128 705-714.

Dexter DL, Barbosa JA \& Calabresi P 1979 N,N-Dimethlyformamideinduced alteration of cell culture characteristics and loss of tumorigeneicity in cultured human colon carcinoma cells. Cancer Research 39 1020-1025.

Du X, Stockklauser-Färber K \& Rosën P 1999 Generation of reactive oxygen intermediates, activation of $\mathrm{NF \kappa B}$ and induction of apoptosis in human endothelial cells by glucose: role of NOS? Free Radical Biology and Medicine 27 752-763.

Esposito K, Nappo F, Marfella R, Giugliano G, Giugliano F, Ciotola M, Quagliaro L, Ceriello A \& Giugliano D 2002 Inflammatory cytokine concentrations are acutely increased by hyperglycaemia in humans: role of oxidative stress. Circulation 106 2067-2072.

Fedorak RN 1990 Adaptation of small intestinal membrane transport processes during diabetes mellitus in rats. Canadian Fournal of Physiology and Pharmacology 68 630-635.

Feingold KR, Moser A, Adi S, Soued M \& Grunfeld C 1982 Small intestinal fatty acid synthesis is increased in diabetic rats. Endocrinology 127 2247-2252.

Gookin JL, Rhoads JM \& Argenzio RA 2002 Inducible nitric oxide synthase mediates early epithelial repair of porcine ileum. American Fournal of Physiology: Gastrointestinal and Liver Physiology $\mathbf{2 8 3}$ G157-G168.

Guo X, Chen LW, Liu WL \& Guo ZG 2000 High glucose inhibits expression of inducible and constitutive nitric oxide synthase in bovine aortic endothelial cells. Acta Pharmacologica Sinica 21 325-328.

Hattori S, Sato N \& Kasai K 2000 High glucose-induced NFкB activation in vascular smooth muscle cells. Cardiovascular Research 46 188-197.

Kilbourn RG \& Griffith OW 1992 Overproduction of nitric oxide in cytokine-mediated and septic shock. Fournal of National Cancer Institute 84 827-831.

Kwon G, Corbett JA, Rodi GP, Sullivan P \& McDaniel ML 1995 Interleukin- 1 beta induced nitric oxide synthase expression by rat pancreatic beta cells: evidence for the involvement of nuclear factor kappa B in the signaling mechanism. Endocrinology 136 $4790-4795$.

Kwon G, Corbett JA, Hauser S, Hill JR, Turk J \& McDaniel ML 1998 Evidence for involvement of the proteasome complex (26S and $\mathrm{NF \kappa B}$ in IL- $1 \beta$-induced nitric oxide and prostaglandin production by rat islets and RINm5F cells. Diabetes 47 583-591.

Linn SC, Morelli PJ, Edry I, Cottongim SE, Szabo C \& Salzman AL 1997 Transcriptional regulation of human inducible nitric oxide synthase gene in an intestinal epithelial cell line. American Fournal of Physiology: Gastrointestinal and Liver Physiology $\mathbf{3 5}$ G1499-G1508.

Loven D, Schedl H, Wilson H, Daabees TT, Stegink LD, Diekus M \& Oberley L 1986 Effect of insulin and oral glutathione on glutathione levels and superoxide dismutase activities in organs of rats with streptozocin-induced diabetes. Diabetes 35 503-507.

Lynas JF, Harriot P, Healy A, McKervey MA \& Walker B 1998 Inhibitors of the chymotrypsin-like activity of proteasome based on di- and tripeptidyl alpha keto aldehydes (glyoxals). Bioorganic Medical Chemical Letters 8 373-378.

McKay DM \& Baird AW 1999 Cytokine regulation of epithelial permeability and ion transport. Gut 44 283-289.

Miralles C, Busquets X, Santos C, Togores B, Hussain S, Rahman I, MacNee W \& Agusti AG 2000 Regulation of iNOS expression and glutathione levels in rat liver by oxygen tension. FEBS Letters $476253-257$.

Moncada S \& Higgs A 1993 The L-arginine-nitric oxide pathway. New England Fournal of Medicine 329 2002-2012. 
Nikulina MA, Andersen HU, Karlsen AE, Darville MI, Eizirik DL \& Mandrup-Poulsen T 2000 Glutathione depletion inhibits IL-1 $\beta$ stimulated NO production by reducing iNOS gene expression. Cytokine 12 1391-1394.

Noh H, Ha H, Yu MR, Kang SW, Choi KH, Han DS \& Lee HY 2002 High glucose increases inducible NO production in cultured rat mesangial cells. Possible role in fibronectin production. Nephron $9078-85$.

Powell LA, Nally SM, McMaster D, Catherwood MA \& Trimble ER 2001 Restoration of glutathione levels in vascular smooth muscle cells exposed to high glucose conditions. Free Radical Biology and Medicine 31 1149-1155.

Savilahti E, Ormala T, Saukkonen T, Sandini-Pohjavuori U, Kantele JM, Arato A, Ilonen J \& Akerblom HK 1999 Jejuna of patients with insulin-dependent diabetes mellitus (IDDM) show signs of immune activation. Clinical and Experimental Immunology 116 $70-77$.

Sharpe PC, Yue KKM, Catherwood MA, McMaster D \& Trimble ER 1998 The effects of glucose-induced oxidative stress on growth and extracellular matrix gene expression of vascular smooth muscle cells. Diabetologia 41 1210-1219.

Son SM, Whalin MK, Harrison DG, Taylor WR \& Griendling KK 2004 Oxidative stress and diabetic vascular complications. Current Diabetes Reports 4 247-252.

Srivastava AK 2002 High glucose-induced activation of protein kinase signaling pathways in vascular smooth muscle cells: a potential role in the pathogenesis of vascular dysfunction. International Fournal of Molecular Medicine 9 85-89.
Stockklauser-Färber K, Ballhausen T, Laufer A \& Rosën P 2000 Influence of diabetes on cardiac nitric oxide synthase expression and activity. Biochimica Biophysica Acta 1535 10-20.

Suh JH, Shenvi SV, Dixon BM, Liu H, Jaiswal AK, Liu RM \& Hagen TM 2004 Decline in transcriptional activity of Nrf2 causes age-related loss of glutathione synthesis, which is reversible with lipoic acid. PNAS $1013381-3386$.

Taylor BS, de Vera ME, Ganster RW, Wang Q, Shapiro RA, Morris SM, Billiar TR \& Geller DA 1998 Multiple NFкB enhancer elements regulate cytokine induction of the human inducible nitric oxide synthase gene. Fournal of Biological Chemistry 273 15148-15156.

Wilmer WA, Dixon CL \& Hebert C 2001 Chronic exposure of human mesangial cells to high glucose environments activates the p38 MAPK pathway. Kidney International 60 858-871.

Xu R, Morales JA, Muniyappa R, Skafar DF, Ram JL \& Sowers JR 1999 IL-1 $\beta$-induced nitric oxide production in rat aortic endothelial cells: inhibition by estradiol in normal and high glucose cultures. Life Science 64 2451-2462.

Zoubi SA, Mayhew TM \& Sparrow RA 1995 The small intestine in experimental diabetes: cellular adaptation in crypts and villi at different longitudinal sites. Virchowes Archives $\mathbf{4 2 6}$ 501-507.

Received 27 July 2004

Accepted 8 September 2004 Made available online as an Accepted Preprint 22 September 2004 